\title{
Hyperdolichocrany in the Medieval Midwestern Kyushuites
}

Teruyuki Hojo

Department of Anatomy and Anthropology, School of Medicine, University of Occupational and Environmental Health, Japan. Kitakyushu 807, Japan

\begin{abstract}
Hyperdolichocrany in the medieval adult males of Midwestern Kyushu (near Kumamoto city), particularly concerning the secular changes of the skull forms, are presented and discussed. While the mean cranial index of the modern Midwestern Kyushuites was mesocranic, the mean cranial index of the medieval Midwestern Kyushuites was hyperdolichocranic of 68.1. Concerning the medieval Kamakura Japanese, Suzuki showed their skull forms to be dolichocrany in the mean cranial index of 74.2. The cranial indexes in the Midwestern Kyushuites have increased from the medieval period to the present-pay.
\end{abstract}

Key words: hyperdolichocrany, cranial index, secular change, head form, medieval Midwestern Kyushuites.

(Received 3 December 1980)

\section{Introduction}

While the present-day Midwestern Kyushuites were shown to be characteristically mesocrany (Matsumoto, 1956), Suzuki et al. (1956) pointed out the remarkable dolichocrany (=a long skull) of the medieval Kamakura Japanese. The author made an anthropometric study of nine samples of the adult male skulls excavated from two medieval sites near Kumamoto city and in this paper points out that the mean cranial index of the skulls was 68.1, hyperdolichocrany. The author describes these medieval hyperdolichocranic types compared with other ethnological groups and discusses secular changes of the Midwestern Kyushuites.

\section{Materials and Methods}

The materials of the adult male skulls investigated in this study were excavated from the two medieval burial sites near Kumamoto city in Midwestern Kyushu (Table 1). Three samples of these materials were partly described by the present author among others (Matsuno et al., 1970). In this paper the author adds the results of six samples of the other medieval burial site (near Kumamoto city) to these results and explains those of his anthropometric studies on these skulls by using main measurements such as: the maximum cranial length, the maximum cranial breadth and the cranial index (the ratio of the latter to the former as a percentage). 
Table 1. A comparison of the main measurements and the index of the calvaria of medieval male adults of Midwestern Kyushuites with others

\begin{tabular}{|c|c|c|c|c|c|c|c|c|c|}
\hline \multirow{2}{*}{ Population } & \multicolumn{3}{|c|}{$\begin{array}{l}\text { Maximum } \\
\text { skull length }\end{array}$} & \multicolumn{3}{|c|}{$\begin{array}{l}\text { Maximum } \\
\text { skull breadth }\end{array}$} & \multicolumn{3}{|c|}{ Cranial index } \\
\hline & $\mathrm{N}$ & Mean & S. D. & $\mathrm{N}$ & Mean & S. D. & $\mathrm{N}$ & Mean & S. D. \\
\hline \multicolumn{10}{|l|}{ Midwestern Kyushuites } \\
\hline Medieval (Hojo) & 9 & 184.0 & 5.76 & 5 & 127.4 & 5.05 & 5 & 68.1 & 1.75 \\
\hline Early modern (Waki) & 13 & 180.1 & 5.84 & 13 & 131.0 & 7.31 & 13 & 72.7 & 3.46 \\
\hline Modern (Matsumoto) & 67 & 179.7 & 6.72 & 67 & 139.4 & 5.92 & 67 & 78.1 & 4. 77 \\
\hline \multicolumn{10}{|l|}{ Kamakuraites } \\
\hline Medieval (Suzuki et al.) & 170 & 184.2 & 7.69 & 168 & 136.5 & 5.60 & 168 & 74.2 & 4. 10 \\
\hline
\end{tabular}

\section{Results and Discussion}

As shown in Table 1, the mean cranial index of the medieval adult male Midwestern Kyushuites is 68.1 (maximum 70.7-minimum 65.7), hyperdolichocrany. The medieval Kamakuraites are dominant in dolichocrany and their mean cranial index is 74.2. While the mean maximum cranial length of the medieval Midwestern Kyushuites is nearly equal to that of the medieval Kamakuraites, the mean maximum cranial breadth of the former shows a remarkable narrowness. The mean cranial index of the medieval Midwestern Kyushuites is smaller than that of the medieval Kamakuraites and is the smallest mean cranial index ever ascribed to the Japanese. In spite of the remarkably remote distance between these two districts, these two populations, belonging to the same period, both show a tendency to dolichocrany. Further, the mean cranial index of the early modern Kumamotoites was described by Waki (1970) to have a dolichocrany of 72.7 (Table 1 ). Taking a long view of secular changes of the skull forms from the medieval period to the present-day, the cranial index of the Midwestern Kyushuites increased and the skull forms become rounder. This tendency of the skull becoming rounder among the Midwestern Kyushuites is common with Japanese of other districts including the Kamakuraites pointed out by Suzuki (1969) and Yanagisawa \& Kondo (1973).

This tendency, that is to say, increase roundness of the skull or head (brachycephalization), which can be traced back to the medieval period, can be observed not only in Midwestern Kyushu, but also in many European countries. It is very difficult to arrive at a clear cause of brachycephalization. We know that no racial changes took place from the medieval period to the present-day in Midwestern Kyushu. On the other hand, domestic animals often exhibit proportions different from those of their ancestors. As one example, the pig's head is shorter and rounder than that of the wild boar. According to this interpretation, brachycephalization can be described as one of the changes referred to in the process of man's self-domestication, that is to say, the development of culture.

\section{References}

Matsumoto, S. (1956): Anthropological study on the skulls of the modern Japanese populations in 
middle Kyushu (Higo). J. Kumamoto Med. Soc., 30: 834-879. (in Japanese without English summary)

Matsuno, S., Hojo, T., Matsuda, A. et al. (1970): On the skulls excavated from the ruins of the earlier medieval period at Midorikawa, Uto city, Kumamoto prefecture. J. Kumamoto Med. Soc., 44: 999-1016. (in Japanese with English summary)

Suzuki, H. (1969): Microevolutional changes in the Japanese population from the prehistoric age to the present-day. J. Fac. Sci., Univ. Tokyo, Sec. V (Anthropology), III, 4: 279-309, Plates $1-7$.

Suzuki, H., Hayashi, T., Tanabe, G. et al. (1956): Characteristics of the Skulls of the Medieval Kamakura People. In: Medieval Japanese skeletons from the burial site at Zaimokuza, Kamakura city. (Anthrop. Soc. Nippon, compiled) Iwanamishoten, Tokyo. pp. 75-148, 155-194. (in Japanese with English summary)

Waki, T. (1970): Anthropological study on the skulls of the Edo period people excavated from Kuwashima island in Ushibuka city, southern Amakusa district, Kumamoto prefecture.

J. Kumamoto Med. Soc., 44: 1031-1091. (in Japanese with English summary)

Yanagisawa, S. \& Kondo, S. (1973): Modernization of physical features of the Japanese with special reference to leg length and head form.

J. Human Ergol. , 2: 97-108.

中世中西部九州人の過長頭型

北條腪幸

産業医科大学第一解剖学教空

要旨：熊本打近郊 2 遺跡から得られた中愢の中西部九州人（男性成人）が過長頭型であることが 記載され，同地方人の頭蓋骨形態の時代的変化が考察された．現代中西部九州人の頭骨指 数の平均值は中頭型であるが，中世の中西部九州人の頭骨指数の平均值は 68.1 で洏長頭 型である。中世鏆倉人に関して，鈴木は頭骨指数の平均值は 74.2 で長頭型であるととを 示した。中四部九州人の頭骨指数は中他加近世を経て現代にかけて増加している．ての 現象はヨーロッパ諸国においても諗められているところの短頭化現象であって，その明確 な原因をつきとめるととは難しいが，人類の自己家童化現象にもとづく変化の1つである と考えるととができよう。

J. UOEH（产業医大誌），3(1)：11-13（1981） 